\title{
On the Approaches to Cultivate Translators and Interpreters in Local Application-oriented Universities
}

\author{
Xiaoru Yang \\ Xi'an Arts and Sciences University, China
} Keywords: Translators and interpreters; cultivation strategies; Local Application-oriented
Universities

\begin{abstract}
In October 2015, the Guiding Suggestion on the Transition of Some Local Undergraduate Universities to Applied Types was formally issued by the Ministry of Education, the National Development and Reform Commission, and the Ministry of Finance, taking the orientation of local applied universities as their guiding principle, and university-enterprise cooperation their main strategy. Based on the Suggestion, this thesis attempts to study the competencies of applied translation talents, and explore the method of cultivating translators from aspects of teaching model, curriculum setting, and scientific research.
\end{abstract}

\section{Introduction}

Under the policy of reform and opening up, the last forty years saw a historic leap in international exchange of China. At present, the depth and breadth of the exchange in politics, economy, culture as well as the daily life such as worldwide purchases and Tmall International market can be described as unprecedented. Under the background of development and international exchanges in depth, translation is particularly important. The traditional translation teaching in our country obviously can not meet the growing demand for translation. The reason is that China's traditional translation teaching is mainly based on literary translation, mainly for the purpose of improving the translation ability of foreign language majors. Its purpose is to improve the ability of foreign language students. This mode can be called translation for teaching, not teaching for translation. In 2006, the Ministry of Education approved the establishment of an undergraduate major in translation. Universities in the country have successively established translation majors, and translation teaching research has also ushered a period of vigorous development. The translation studies in the domestic translation circle have also made a lot of researches on translation teaching and translation theories. By 2017, China has set up BTI in more than 200 universities. The author's school established a BTI in June 2017. In October 2015, the Ministry of Education, the National Development and Reform Commission, and the Ministry of Finance formally issued the Guiding Opinions on Local Application-oriented Universities, after that the education aims of local colleges and universities are clarified. Local Application-oriented universities face a major transformation in terms of teaching methods and programme construction. From a macro perspective, local application-oriented colleges and universities should try to find ways to achieve cooperation and integration between universities and enterprises. In terms of curriculum construction, emphasis should be placed on application and the needs of social development. At the same time, we should attach great importance to the transformation of scientific research resources into teaching resources. As far as translation major is concerned, the training objectives, curriculum, and scientific research of Local application-oriented universities have their own characteristics. Translation practise is the core of the students of translation .

\section{The Abilities of the Students of Translation in Local Application-oriented Universities}

Local Application-oriented universities cultivate their students to serve local social and economic development. Generally, the correct view of translation, solid bilingual knowledge, extensive cultural knowledge, and professional service consciousness should be the core competences of students of translation in local universities. 
Nida, an American linguist, pointed out that some translation theorists have attempted to specify many formulas to exactly how to translate in each case. But there are too many different situations and too many different genres. There are too many different kinds of readers, too many translation and communication purposes, what we need is not the complicated formulas and theories, but the translators with the knowledge of culture, the proper expression of language, and skills of translation. [7] The ability of a translator is not taught by the teacher, but by constant and a large number of translation practices under the guidance of some basic translation skills. Practice has proved to be the core for students of translation and practical translation exercises combined with the actual needs of the society can make the translator's ability improve.

A solid bilingual foundation is the basic of a translator's ability. According to the current practice research, the problems of students' language ability can be summarized as: narrow knowledge, inaccurate English, poor Chinese. During the four years of university, students should continuously improve their language skills and encyclopedic knowledge in response to these problems.

Extensive cultural knowledge is the premise of translation. The reason is: "A translator must be a true literary person. First of all he must master two languages, but he cannot truly master the language without understanding the social culture. Not only does it need to have an in-depth understanding of foreign culture, but it also requires an in-depth understanding of their own culture, and more importantly, constantly comparison between the two cultures is also needed in translation.Mr. Wang Zuoliang's remarks vividly summarize the relationship between translation and culture: the translator deals with not individual words that he faces but the two major cultures." In the process of translation, both the understanding of the original text and the expression in translation, the translator must have abundant encyclopedic knowledge and common sense.

In order to do a good job in translation, the translator must be a living encyclopedia. This is certainly an idealized goal, but each translator should work hard toward this goal. Undergraduate students should expose to courses such as Ancient Chinese, Modern Chinese, Chinese Classical Works, Chinese Modern and Contemporary Literature, Advanced Chinese Writing, and Logic. They should lay a solid foundation for Chinese studies, develop their thinking skills, and improve their awareness and understanding of culture .

Service consciousness. At present, the acceleration of the development of networks and electronic technologies has had a huge impact on translation, which has spawned new forms of translation, such as crowd-sourced translation and remote translation. These new forms of translation have higher requirements for language services. Under the background of the continuous evolution of machine translation, crowd-sourced translation, and remote translation, factors such as market and patronage have a profound impact on translation today. On one hand, It is necessary for translators to increase their awareness of language services to customers and audiences; on the other hand, they should not ignore the "loyalty" principle to the original text, and should not seek to "radical functionalism".

\section{The Strategies of Cultivating Students of Translation in Local Application-oriented Universities}

Defining the Goal of Teaching. Local application-oriented college translation majors must have their own characteristics and have clear teaching objectives. When carrying out the teaching programme, it is necessary to combine the local economic development trend and industrial structure to build a distinctive translation class, so as to enhance the practicality of teaching content. On the one hand, colleges and universities conducting the training of translators must identify talents who can be trained to serve local economic development and who can communicate effectively with people from other countries. This requires that they should acquire a certain amount of cultural knowledge and good professional qualities in translation. On the other hand, strengthening the cultivation of applied talents will enable them to have better development in the field of translation.

Changing the Traditional Curriculum System. The knowledge and skills of translation majors mainly refer to students' language ability, translation ability and general education. Therefore, when 
setting up a translation class, it is mainly necessary to consider these three aspects. In order to meet the needs of modern society for the development of applied talents, the classroom system can be divided into general courses, professional basic courses, professional-oriented courses, and translation practice courses. When setting up these courses, the first emphasis is on English translation theories. In the process of translation, we found that cultural differences makes translation difficult.we also found that only by practice can the translation ability be developed. For different students, we should offer specific training, such as for some students who want to gain further education,we need to teach them some theoretical knowledge. Chinese culture general theory, western culture general theory, ancient Chinese and cross-cultural communication are offered to help the students to broaden their horizon. Through the design of these contents, students can be more handy when translating. In translation practice classes, different learning projects such as translation practice, interpretation, listening and business translation are required. In addition, in teaching, it is necessary to attach importance to practical teaching content. These should become important standards for assessing their abilities. Only in this way can we develop applied translators.

Strengthening the Construction of Teacher Teams. In the reform of foreign language teaching, team building of translation teachers is a very important task. As long as we have an excellent team of teachers, we can formulate clear teaching goals, make reasonable designs for the classroom, and select appropriate teaching materials. To explore scientific and efficient teaching methods to ensure the quality of teaching, and to train the best applied translators. However, judging from the current situation in China, teachers engaged in translation majors are mainly from foreign language majors. The main problem they have is the lack of practical translation experience and inadequate understanding of the various changes in the market. The content of teaching may be lagged behind. Faced with this situation, we must do a good job of cooperation between schools and enterprises and give full play to the advantages of professional translators and interpreters. They are more capable of practicing and can teach the students some skills that they can master in practical work. This is a good enrichment of teachers, so that students can get better training. Translation teachers can also extract translation teaching theory from the translation practice, hence promote scientific research.

Changing the Traditional Teaching Mode. In the development of modern foreign language colleges and universities, it is necessary to speed up the development of school transformation. In the training of talents, we must pay more attention to the practical application ability and localization of translators. We should actively explore the training methods of modern translators. In the actual teaching, it is necessary to actively promote teaching methods for real tasks. For example, some case teaching and project teaching. Some practical corporate contracts and engineering projects allow students to perform group translations. First, students translate according to the actual translation work, teachers can then comment on the translation of each group of students. Students can also comment on their translated texts each other, product brainstorm ideas, and finally select the best translations that everyone thinks are more practical. In the course, we should try our best to reduce lectures on theory, so as to give students more time to think and translate. This kind of translation test also directly reflects the actual situation of teaching and the students' translation ability, and in this process we can also find out the deficiencies in teaching, so that in the subsequent teaching they can be corrected. And schools can set up relevant practical award programs to encourage students to practice more.

Strengthening University-enterprise Cooperation. When local colleges and universities are training applied translators, they are mainly to enable them to meet the needs of society and to keep up with the "Belt and Road" development strategy pursued by modern countries. Therefore, when colleges and universities train talents, they must go out and let translators truly serve the society. The university-enterprise cooperation adopts the management model of the translation company to train the students. It draws heavily on the management experience of the interpreters in the company, and through cooperation with the company, it also enriches the corpora of the university when it conducts translation teaching. It plays an important role in training applied translators. 


\section{Conclusion}

In order to adapt to the development of this society, translation teaching must change the traditional concept, regard the application type as the main training core, strengthen the cooperation between the translation industry and the school, and improve the students' comprehensive ability and innovation ability. Local colleges and universities should attach more importance on internships and training of students so as to cultivate more translation talents who can meet the needs of the market.

\section{References}

[1] Qingqing Zhang, Comment on Translation teaching for undergraduates: situation and strategy, Journal of Hengyang Normal university, 2017,8

[2] Shufang Huang, On current situation of translation teaching in local university and feasible strategy, Education and Profession, 2014,9

[3] Xiying Cao, The reformational trends of Translation teaching, Journal of Southwest University of Nationalities (Humanities and Social Sciences Edition), 2009,3

[4] Heping Liu, Translation Teaching Model: Theory and Application, Chinese Translation, 2013, 2

[5] Ruilin Li , from translation ability to translator literacy: veer of translation teaching goal , Chinese translation, 2011,1

[6] Yan Li, toward a design of translation teaching based on vocational consciousness training, Shanghai Translation, 2015,3

[7] Nida, E.A.Translating Meaning[M].San Diams:English Language Institute, 1982.

[8] Jackendoff, R.Consciousness and the Computational Mind[M].Cambridge, MA:MIT Press, 1987.

[9] Richards. "Toward a Theory of Translating" in Wright (ed) .Studies in Chinese Thought.Chicago:University of Chicago Press, 1953:247-262.

[10] Teaching Models for Translation Major: Professional Competence-oriented

[11] Li Defeng.Translation curriculum and pedagogy:Views of administrators of translation services[J].Target, 2007, 19 (1) :105-133.

[12] Kiraly, Don.Project-Based Learning:a Case for Situated Translation[J].Meta, 2005, 50 (4) :1098-1111. 